This item was submitted to Loughborough's Research Repository by the author.

Items in Figshare are protected by copyright, with all rights reserved, unless otherwise indicated.

\title{
Concurrent wet and dry hydrological extremes at the global scale
}

PLEASE CITE THE PUBLISHED VERSION

https://doi.org/10.5194/esd-11-251-2020

\section{PUBLISHER}

(c) the authors. Published by Copernicus $\mathrm{GmbH}$

\section{VERSION}

VoR (Version of Record)

\section{PUBLISHER STATEMENT}

This work is made available according to the conditions of the Creative Commons Attribution 4.0 International (CC BY 4.0) licence. Full details of this licence are available at: http://creativecommons.org/licenses/by/4.0/

\section{LICENCE}

CC BY 4.0

\section{REPOSITORY RECORD}

De-Luca, Paolo, Gabriele Messori, Robert Wilby, Maurizio Mazzoleni, and Giuliano Di Baldassarre. 2020. "Concurrent Wet and Dry Hydrological Extremes at the Global Scale". figshare.

https://hdl.handle.net/2134/38100. 


\title{
Concurrent wet and dry hydrological extremes at the global scale
}

\author{
Paolo De Luca ${ }^{1,2,3,4}$, Gabriele Messori ${ }^{2,5}$, Robert L. Wilby ${ }^{1}$, Maurizio Mazzoleni ${ }^{2,3}$, and \\ Giuliano Di Baldassarre ${ }^{2,3}$ \\ ${ }^{1}$ Geography and Environment, Loughborough University, Loughborough, LE11 3TU, UK \\ ${ }^{2}$ Department of Earth Sciences, Uppsala University, Uppsala, 75236, Sweden \\ ${ }^{3}$ Centre of Natural Hazards and Disaster Science (CNDS), Uppsala, 75236, Sweden \\ ${ }^{4}$ Department of Water and Climate Risk, Vrije Universiteit Amsterdam, Amsterdam, $1081 \mathrm{HV}$, the Netherlands \\ ${ }^{5}$ Department of Meteorology, Stockholm University and Bolin Centre for Climate Research, \\ Stockholm, 10691, Sweden \\ Correspondence: Paolo De Luca (p.deluca@vu.nl)
}

Received: 16 May 2019 - Discussion started: 17 June 2019

Revised: 16 February 2020 - Accepted: 22 February 2020 - Published: 10 March 2020

\begin{abstract}
Multi-hazard events can be associated with larger socio-economic impacts than single-hazard events. Understanding the spatio-temporal interactions that characterize the former is therefore of relevance to disaster risk reduction measures. Here, we consider two high-impact hazards, namely wet and dry hydrological extremes, and quantify their global co-occurrence. We define these using the monthly self-calibrated Palmer Drought Severity Index based on the Penman-Monteith model (sc_PDSI_pm), covering the period 1950-2014, at $2.5^{\circ}$ horizontal resolution. We find that the land areas affected by extreme wet, dry, and wet-dry events (i.e. geographically remote yet temporally co-occurring wet or dry extremes) are all increasing with time, the trends of which in dry and wet-dry episodes are significant ( $p$ value $\ll 0.01$ ). The most geographically widespread wet-dry event was associated with the strong La Niña in 2010. This caused wet-dry anomalies across a land area of 21 million $\mathrm{km}^{2}$ with documented high-impact flooding and drought episodes spanning diverse regions. To further elucidate the interplay of wet and dry extremes at a grid cell scale, we introduce two new metrics: the wet-dry (WD) ratio and the extreme transition (ET) time intervals. The WD ratio measures the relative occurrence of wet or dry extremes, whereas ET quantifies the average separation time of hydrological extremes with opposite signs. The WD ratio shows that the incidence of wet extremes dominates over dry extremes in the USA, northern and southern South America, northern Europe, north Africa, western China, and most of Australia. Conversely, dry extremes are more prominent in most of the remaining regions. The median ET for wet to dry is $\sim 27$ months, while the dry-to-wet median ET is 21 months. We also evaluate correlations between wet-dry hydrological extremes and leading modes of climate variability, namely the El Niño-Southern Oscillation (ENSO), Pacific Decadal Oscillation (PDO), and Atlantic Multi-decadal Oscillation (AMO). We find that ENSO and PDO have a similar influence globally, with the former significantly impacting ( $p$ value $<0.05)$ a larger area $(18.1 \%$ of total sc_PDSI_pm area) compared to the latter (12.0\%), whereas the AMO shows an almost inverse pattern and significantly impacts the largest area overall (18.9\%). ENSO and PDO show the most significant correlations over northern South America, the central and western USA, the Middle East, eastern Russia, and eastern Australia. On the other hand, the AMO shows significant associations over Mexico, Brazil, central Africa, the Arabian Peninsula, China, and eastern Russia. Our analysis brings new insights on hydrological multi-hazards that are of relevance to governments and organizations with globally distributed interests. Specifically, the multihazard maps may be used to evaluate worst-case disaster scenarios considering the potential co-occurrence of wet and dry hydrological extremes.
\end{abstract}




\section{Introduction}

Natural hazards can interact in diverse ways, leading to multi-hazard events that can exacerbate disaster losses when compared to single-hazard occurrences (Zscheischler et al., 2018). Examples of multi-hazards are the co-occurrence of heavy precipitation or flooding with wind damage from extratropical cyclones (De Luca et al., 2017, 2020; Waliser and Guan, 2017), storm surge combined with fluvial flooding in deltas (Ward et al., 2018), flood episodes along with droughts (Collet et al., 2018), and landslides triggered by earthquakes (Kargel et al., 2016). Such combinations can lead to situations beyond the worst-case scenario planned by emergency managers, (re)insurance companies, businesses, and governments and thus present a critical challenge for disaster risk reduction (Zscheischler et al., 2018). The relevance of multihazards has been recognized by scientific and stakeholder communities, and both have devoted significant efforts to the topic over the past decade (e.g. Forzieri et al., 2016; Gallina et al., 2016; Gill and Malamud, 2014; Kappes et al., 2012; Terzi et al., 2019; Zscheischler et al., 2018). Indeed, the United Nations Sendai Framework for Disaster Risk Reduction (UNISDR, 2015) now advocates multi-hazard approaches to disaster risk reduction.

Analysis of multi-hazards is highly relevant given anthropogenic climate change. Events such as floods and droughts already have significant humanitarian and socio-economic impacts (Alfieri et al., 2016; Barredo, 2007; Di Baldassarre et al., 2010; Jonkman, 2005; Naumann et al., 2015; Van Loon et al., 2016; Zhang et al., 2011) and are expected to become more frequent and/or severe in the future (Arnell and Gosling, 2016; Dai, 2011a, 2012; Hirabayashi et al., 2013; Hirsch and Archfield, 2015; IPCC, 2012; Milly et al., 2002), albeit with a large degree of uncertainty (e.g. Orlowsky and Seneviratne, 2013). Numerous studies have investigated the combination of flood and drought events or, more generally, wet and dry hydrological extremes at local and regional scales for both present and future climates (e.g. Berton et al., 2017; Collet et al., 2018; Deangelis et al., 1984; Di Baldassarre et al., 2017; Gil-Guirado et al., 2016; Oni et al., 2016; Parry et al., 2013; Pechlivanidis et al., 2017; QuesadaMontano et al., 2018; Yan et al., 2013; Yoon et al., 2018). Examples include the analysis of abrupt drought-flood transitions in river basins in China (Yan et al., 2013) and in England and Wales (Parry et al., 2013). There is also the dynamical interplay between society and hydrological extremes, intended as the mutual influence of human activities on floods and droughts (Di Baldassarre et al., 2017), and indices assessing the long-term evolution of vulnerability and adaptation to these hazards (Gil-Guirado et al., 2016). Other studies consider wet-dry interactions from a statistical perspective (Collet et al., 2018) or have related these two independent hazards to large-scale modes of climate variability (Cai and
Rensch, 2012; Lee et al., 2018; Nobre et al., 2017; Siegert et al., 2001; Ward et al., 2014; Yoon et al., 2018).

Quantifying wet and dry (also extreme) hydrological events at both regional and global scales is a non-trivial task. Some commonly used metrics include the Palmer Drought Severity Index (PDSI) (Dai et al., 2004; Palmer, 1965), the Standardized Precipitation Index (SPI) (McKee et al., 1993, 1995), and the Standardized Precipitation Evapotranspiration Index (SPEI) (Vicente-Serrano et al., 2010). For instance, the PDSI was used to evaluate the combined effect of the Pacific Decadal Oscillation (PDO) and El Niño-Southern Oscillation (ENSO) on global wet and dry changes over land, showing that when these two modes are in phase (e.g. El Niñowarm PDO) wet and dry events are amplified (Wang et al., 2014). The PDSI and SPEI have also been used to quantify wet and dry trends over China, with generally good agreement between the two (Chen et al., 2017). At the global scale, the SPI and SPEI were used to explore wet and dry links with ENSO, PDO, and the North Atlantic Oscillation (NAO) (Sun et al., 2016). The study found that ENSO has the greatest spatial impact for wet and dry changes, followed by the PDO with an effect in North America and eastern Russia as well as the NAO with an affect on Europe and northern Africa. The SPI has also been used in a global multi-model ensemble analysis of future projections in pluvial and drought events (Martin, 2018). This revealed that more severe pluvial events are expected in regions that are already wet, and the same applies for more severe droughts in dry areas, although the overall "wet gets wetter, dry gets drier" paradigm may have some limitations, since when the paradigm is applied over land it does not hold as expected because of changes in atmospheric circulation, horizontal gradients of temperature, and relative humidity (e.g. Byrne and O'Gorman, 2015; Yang et al., 2018).

In this study, we adopt a relatively broad definition of multi-hazard events, i.e. the temporal (yet spatially separate) co-occurrence of wet and dry hydrological extremes at the global scale, quantified following De Luca et al. (2017). We emphasize that the term "hydrological extreme" does not necessarily imply observed flooding or drought events unless explicitly mentioned, and we always make use of this term when referring to the sequential occurrence of extremes with opposite sign (i.e. wet and dry). The relevance of both types of multi-hazards is evident. Stakeholders with geographically diverse portfolios, such as governments, international bodies, relief agencies, non-governmental organizations (NGOs), financial markets, and (re)insurance companies, could all benefit from a robust statistical understanding of the co-occurrence of natural hazards. Many also need to manage risks from the occurrence of damaging events in rapid succession, whose compound impacts may exceed the sum of expected impacts from isolated wet and dry extremes. Similarly, estimates of the range of times that intervene be- 
tween the two different extremes can inform disaster preparedness and prevention measures. Finally, the growth of national economies that depend heavily on agricultural outputs and other natural resources such as hydropower can be impacted by sequential hydrological extremes (Zampieri et al., 2017; Zhang et al., 2015).

Notwithstanding their socio-economic relevance, concurrent wet and dry hydrological extreme events at the global scale have seldom been addressed in the literature. One early study did consider combinations of wet and dry extremes via observed PDSI for two thresholds (wet, PDSI $>3$ and dry, PDSI $<-3$ ) (Dai et al., 2004). This showed that the total global land area $\left(60^{\circ} \mathrm{S}-75^{\circ} \mathrm{N}\right)$ impacted by wet-dry extremes increased between 1950 and 2002, with marked changes occurring from the early 1970s and surface warming being identified as the driver of these changes after the mid1980s. We extend this analysis by (i) using an updated time series (1950-2014); (ii) introducing new metrics for assessing concurrent wet-dry extremes; (iii) presenting findings at monthly and annual resolution; and above all (iv) defining the most geographically widespread multi-hazard events occurring within each month, instead of simply considering extreme observations with PDSI $>3$ and PDSI $<-3$. We explore these multi-hazard properties using the monthly self-calibrated PDSI dataset based on the Penman-Monteith model (sc_PDSI_pm) (Dai, 2017; Sheffield et al., 2012). We specifically address the following questions.

i. To what extent has the global area impacted by wet, dry, and concurrent wet-dry hydrological extreme events changed?

ii. What were the most geographically widespread extreme wet, dry, and concurrent wet-dry events? And what is the associated documentary evidence of extreme conditions during these periods?

iii. How comparatively frequent were wet or dry extremes in the past?

iv. What is the most likely time interval between opposite extremes at a given location?

v. How are wet and dry hydrological extremes linked with dominant modes of climate variability?

\section{Data and methods}

\subsection{Data}

We used the self-calibrated monthly mean Palmer Drought Severity Index based on the Penman-Monteith model (sc_PDSI_pm) (Dai, 2017; Sheffield et al., 2012) for the 1950-2014 period at $2.5^{\circ}$ horizontal resolution (freely available https://rda.ucar.edu/datasets/ds299.0/, last access: 6 March 2020). Self-calibration enables a more consistent comparison between different climatic regions, and the Penman-Monteith model outperforms the original PDSI Thornthwaite algorithm (Wells et al., 2004) in representing potential evaporation at the global scale (Sheffield et al., 2012). From this dataset, we obtain extreme wet and dry monthly observed events by conditioning the data on sc_PDSI_pm $\geq 3$ and sc_PDSI_pm $\leq-3$, respectively. These two thresholds specify very moist spells and severe droughts. Only grid cells with time series having $\geq 95 \%$ of observations over the period of interest are considered. We acknowledge that the sc_PDSI_pm $2.5^{\circ}$ horizontal resolution is relatively coarse, and hence highly localized processes, such as convective precipitation in the tropics and midlatitudes (in summer), may not be well represented. However, we assert that the sc_PDSI_pm is adequate since our analysis is global and intended to provide a broad overview of concurrent wet and dry extremes.

We further analyse three climate modes of variability known to affect regional and global precipitation patterns: the Niño3.4 (Rayner et al., 2003; Trenberth, 1997), PDO (Mantua and Hare, 2002), and Atlantic Multi-decadal Oscillation (AMO) (Schlesinger and Ramankutty, 1994). All these climate indices are at monthly time resolution from 1950 to 2014, as issued by the National Oceanic and Atmospheric Administration (NOAA).

\subsection{Methods for identifying extreme wet, dry, neutral, and wet-dry events}

First, we calculate the percentage of total land area $\left(\mathrm{km}^{2}\right)$, derived from our sc_PDSI_pm dataset impacted by the most widespread monthly extreme wet (sc_PDSI_pm $\geq 3$ ) and dry (sc_PDSI_pm $\leq-3)$ hydrological events, along with neutral $(-3<$ sc_PDSI_pm $<3)$ and extreme wet plus extreme dry events within the period 1950-2014. Monthly extreme wet events were calculated following De Luca et al. (2017) by (i) computing the wet annual maxima (AMAX), i.e. the highest monthly sc_PDSI_pm observations within each calendar year at each grid cell, provided that they satisfy sc_PDSI_pm $\geq 3$; (ii) counting the number of wet AMAX observations occurring on the same date from all the grid cells (e.g. in December 2010 a total of 217 grid cells reported a wet AMAX); and (iii) taking the extreme wet event with the most geographically widespread impacts, i.e. largest impacted area, during 1950-2014. Within all the calculations of the impacted area we considered the difference in the area size of grid cells at different latitudes. Therefore, we computed the exact grid cell area using the gridarea function of the Climate Data Operators (CDO) software (freely available https://code.mpimet.mpg.de/, last access: 6 March 2020).

Extreme dry events were calculated in a similar way as extreme wet events except that in place of AMAX the sc_PDSI_pm annual minima (AMIN), i.e. the lowest monthly sc_PDSI_pm observations within each year, were used to compute the extreme events, provided that they satisfied sc_PDSI_pm $\leq-3$. Neutral events were iden- 
tified as follows: (i) extract the sc_PDSI_pm AMAX of (non-extreme) wet events $(0 \leq$ sc_PDSI_pm $<3$ ); (ii) extract the sc_PDSI_pm AMIN for (non-extreme) dry events $(-3<$ sc_PDSI_pm $<0)$; (iii) pool within the same dataset both (non-extreme) wet AMAX and dry AMIN events by month; (iv) compute the most widespread neutral events by month as per above. Lastly, concurrent extreme wet-dry events were calculated by summing their individual areas for each month. A Mann-Kendall test (Kendall, 1975; Mann, 1945) was performed to assess any significant trends within each time series. Relative Sen's slopes (Sen, 1968) with $p$ values were also computed.

Second, to establish whether the most widespread extreme wet, dry, and wet-dry events were solely due to chance, a bootstrapping analysis of $n=10000$ samples was performed using the original sc_PDSI_pm dataset. The bootstrapping steps were as follows: (i) prepare the complete global (i.e. all grid cells) sc_PDSI_pm dataset from 1950 to 2014; (ii) sample from all grid cells together, with replacement, the sc_PDSI_pm values $n=10000$ times from this global dataset; (iii) calculate $n=10000$ wet and $n=10000$ dry events with the same algorithm used above for the original dataset; (iv) take the impacted area of the most geographically widespread wet and dry extreme events for each sample; (v) calculate the 2.5th and 97.5th percentiles of the extreme wet and dry event area. Statistical significance was assessed by checking whether the observed extreme wet and dry percentage $(\%)$ of total impacted areas fell outside the 2.5th and 97.5th percentiles of the bootstrapped events. If this was the case, the observations were considered statistically significant at the $5 \%$ level ( $p$ value $<0.05$ ).

Lastly, to test whether the sc_PDSI_pm values obtained during the most widespread wet, dry, and wet-dry events were spatially autocorrelated we computed the Moran's I correlation coefficients (Li et al., 2007; Moran, 1950) using the geosphere_v1.5-10 and ape_v5.3 R packages. The Moran's I correlation coefficient can have values between -1 and 1 . When $I>0$ it indicates the existence of clustering between similar values; when $I<0$ it indicates clustering between dissimilar values, and when $I=0$ the values are randomly distributed in space. Statistical significance was assessed under the null hypothesis that there is no spatial autocorrelation between values. Moran's $I$ was computed for the most widespread wet, dry, and wet plus dry hydrological extremes.

\subsection{Wet-dry metrics}

The wet-dry (WD) ratio is derived on a cell-by-cell basis by taking the natural logarithm of the total number of extreme wet observations (months with sc_PDSI_pm $\geq 3$ ) divided by the total number of extreme dry observations (months with sc_PDSI_pm $\leq-3$ ) over the 1950-2014 period:
$\mathrm{WD} \mathrm{ratio}_{h}=\ln \left(\frac{n_{i, h}}{n_{j, h}}\right)$,

where $h$ refers to a single grid cell, and $n_{i}$ and $n_{j}$ are the total number of wet and dry extremes, respectively. The WD ratio gives information about the propensity of a given area to be more affected by wet or dry extremes. Thus, a WD ratio $>0$ signifies that wet extremes outnumber dry extremes, and a WD ratio $<0$ indicates a predominance of dry extremes over wet ones. The natural logarithm was used to narrow the range of WD ratio values and to separate the wet-dominated versus dry-dominated regions by sign. As a caveat, we note that the WD ratio does not account for the different intensities of wet and dry extremes.

Wet-to-dry and dry-to-wet transitions, here named extreme transitions (ETs), were assessed for each grid cell by computing the average time interval (months) between these extremes within the 1950-2014 period. More specifically, ET for wet to dry was derived as follows for each grid cell: (i) extract both wet (sc_PDSI_pm $\geq 3$ ) and dry (sc_PDSI_pm $\leq-3$ ) extreme observations from the entire (1950-2014) sc_PDSI_pm dataset; (ii) order extreme observations by time, from oldest to the most recent; (iii) retain only the earliest extreme observation in the case of consecutive extreme dry observations and the latest in the case of consecutive wet observations; (iv) calculate the time interval (monthly difference) between wet and dry extreme observations within the time series; and (v) take the average of the time interval. The same algorithm was applied for calculating ET from dry to wet for each grid cell, with the only difference being in step (iii) in which the earliest wet and latest dry extreme observations were kept and in step (iv) in which the time interval was calculated between dry-to-wet transitions.

\subsection{Correlation with climate indices}

Associations between extreme wet-dry hydrological extremes and the three modes of climate variability (Niño3.4, PDO, and AMO) were assessed using the Spearman's rank correlation test (Corder and Foreman, 2014). Specifically, the correlations were performed for each grid cell only for monthly wet and dry extreme observations (sc_PDSI_pm $\geq 3$ and sc_PDSI_pm $\leq-3$ ) within the 1950-2014 period, paired with the corresponding monthly values of Niño3.4, PDO, and AMO. The Spearman's test does not require data to be normally distributed, making it well suited to the analysis of extreme PDSI values. Since the number of correlation tests performed is large ( $>2700$ ) there is a risk of incurring statistically significant results simply by chance. Thus, to account for Type I errors (or "false positives") the Bonferroni correction (Bonferroni, 1936; Sedgwick, 2014) was applied to all $p$ values.

Finally, since Niño3.4 may interact with other modes of climate variability, we removed this signal when correlating the PDO and AMO with sc_PDSI_pm extreme wet and 
dry observations by performing partial correlations with the $\mathrm{R}$ package ppcor_v1.1. Partial correlations represent the relationship between two random variables after removing the effect of one or more other random variables. Here, the partial correlation between two variables, $x_{i}$ (e.g. PDO) and $x_{j}$ (e.g. sc_PDSI_pm), given a third variable $x_{k}$ (e.g. Niño3.4) is defined as follows (Kim, 2015; Whittaker, 2009):

$r_{i j \mid k}=\frac{r_{i j}-r_{i k} r_{j k}}{\sqrt{1-r_{i k}^{2}} \sqrt{1-r_{j k}^{2}}}$,

where $r$ is the new Spearman's rank partial correlation coefficient. As a limitation of this approach, we note that our correlations with modes of climate variability do not strictly focus on concurrent wet-dry hydrological extremes. Therefore, our results, although in agreement with extreme wet-dry spatial patterns, do not entirely explain these multi-hazard events.

\section{Results}

\subsection{Land area impacted by extreme wet, dry, neutral, and wet-dry events}

The percentage (\%) of total global land area impacted by the most widespread extreme wet, dry, and neutral events is shown in Fig. 1 at both monthly and annual resolutions from 1950 to 2014. For extreme wet events (sc_PDSI_pm $\geq 3$ ) the average monthly impacted area over the 65 -year period is $2.2 \%$ (Fig. 1a). The most widespread wet event occurred in December 2010 (7.8\%; discussed in Sect. 3.2). The Mann-Kendall test indicates positive, though non-significant, trends at both monthly and annual scales (Fig. 1a and b). The non-significant observed growth in extreme wet area is contrary to previous research, showing a significant decline in (very) wet land areas (Dai, 2011b; Dai et al., 2004). However, varying the sc_PDSI_pm threshold used to define the extremes points to the sensitivity of the results to this choice. Indeed, at monthly resolution, when using sc_PDSI_pm $\geq 2$ the wet land area decreases significantly (Sen's slope $=-5.4 \times 10^{-4}$ and $p$ value $<0.01$; not shown), while when using a higher threshold of sc_PDSI_pm $\geq 4$, the wet land area increases significantly (Sen's slope $=4.9 \times 10^{-4}$ and $p$ value $\ll 0.01$; not shown).

For extreme dry events (sc_PDSI_pm $\leq-3$ ) the average impacted area at monthly resolution is $2.4 \%$, and the largest 1-month event occurred in January 2003 (8.6\%; Fig. 1c and discussed in Sect. 3.2). In this case, the Mann-Kendall test indicates a positive and statistically significant trend (Sen's slope $=1.7 \times 10^{-3}$ and $p$ value $\ll 0.01$ ). This signifies that the total area subject to severe drought increased between 1950 and 2014. The trend observed at monthly resolution is stronger and more evident from the beginning of the 1980s when aggregating data over annual timescales (Fig. 1d; Sen's slope $=2.7 \times 10^{-1}$ and $p$ value $\ll 0.01$ ). This result agrees with previous studies showing a global increase in drought risk, attributed to anthropogenic climate change, in both observations and climate model simulations (Dai, 2011a, 2012; Dai et al., 2004; Marvel et al., 2019). Such changes in drought are linked to anomalies in tropical sea surface temperatures (SSTs) and driven by both El Niño and La Niña phases, along with increased surface warming from the 1980s.

The neutral events $(-3<$ sc_PDSI_pm $<3)$ affected on average $13.6 \%$ of the global land area over the 19502014 period, with the largest reaching $30.4 \%$ (Fig. 1e, monthly resolution). The Mann-Kendall test shows a negative and significant trend (Sen's slope $=-1.9 \times 10^{-3}, p$ value $\ll 0.01$ ), once again stronger and more evident at annual timescales (Fig. 1f; Sen's slope $=-3.2 \times 10^{-1}$ and $p$ value $\ll 0.01$ ). Such a reduction in the area under neutral conditions is consistent with the observed increasing trend of both extreme wet and dry events. The neutral events show strong seasonality, with peaks of impacted area occurring during December. The fact that $73.4 \%$ of the global sc_PDSI_pm land area is in the Northern Hemisphere may introduce a bias in the temporal distribution of the extreme and neutral events. For example, boreal and austral winters over the Northern and Southern Hemisphere mid-latitudes are typically wetter than their respective summers. The larger land area in the Northern Hemisphere means there is a greater chance that more wet events are observed during boreal wintertime (December to February) than during austral wintertime (June to August), thereby driving the peaks in seasonality in Fig. 1.

Finally, the area with 1-month concurrent wet-dry hydrological extreme events (Fig. 1g) shows an increasing and statistically significant trend (Sen's slope $=1.08 \times 10^{-3}$ and $p$ value $\ll 0.01$ ), consistent with shorter records (Dai et al., 2004). The mean monthly total global land area with concurrent wet-dry extreme events is $4.6 \%$, and the most widespread event impacted a total land area of $13.7 \%$ (discussed in Sect. 3.2). As per dry and neutral events, annually aggregated data show a stronger trend (Fig. 1h; Sen's slope $=3.0 \times 10^{-1}$ and $p$ value $\left.\ll 0.01\right)$ and a greater increase in the wet-dry impacted area from the 1980s.

\subsection{Concurrent global flood and drought events}

We next consider the single most extensive wet, wet-dry, and dry events and show that they match reports of severe flood and drought events. The most widespread global extreme wet event was also the most widespread wet-dry event and occurred in December 2010 (Fig. 2a). Recorded events matching this occurrence include the devastating Queensland floods in Australia (BBC, 2010a; Smith et al., 2013; Trenberth and Fasullo, 2012; Zhong et al., 2013), heavy floods and landslides in south-east India which killed more than 180 people (Reliefweb, 2010), widespread flooding and landslides in Colombia and Venezuela causing about 
(a)

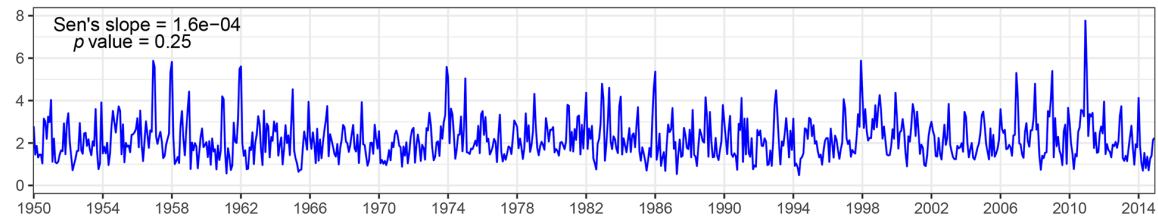

(b) 3

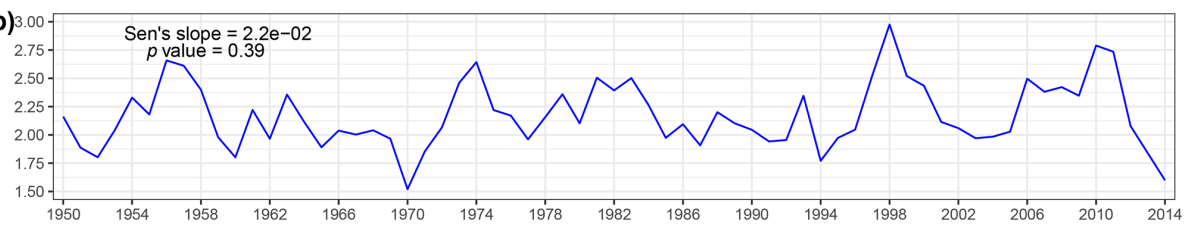

(c)
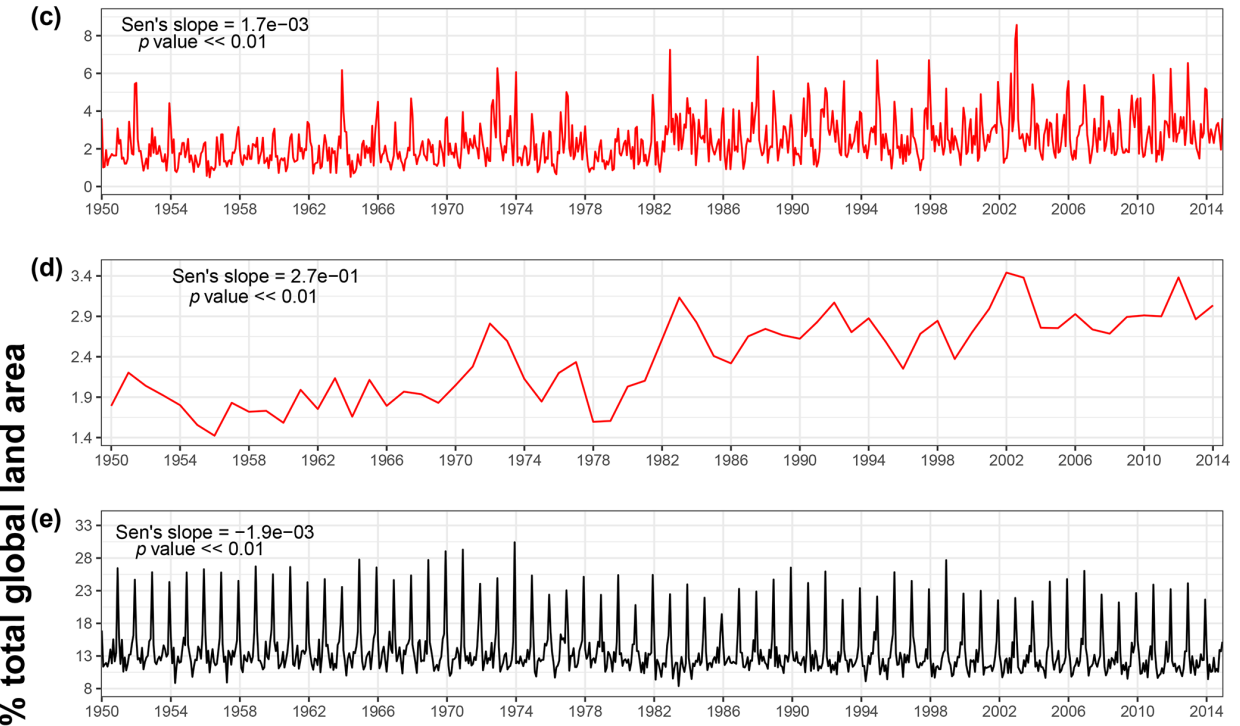

(f)

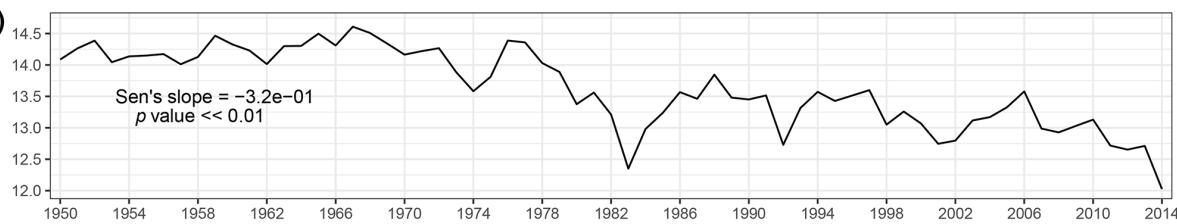

(g)

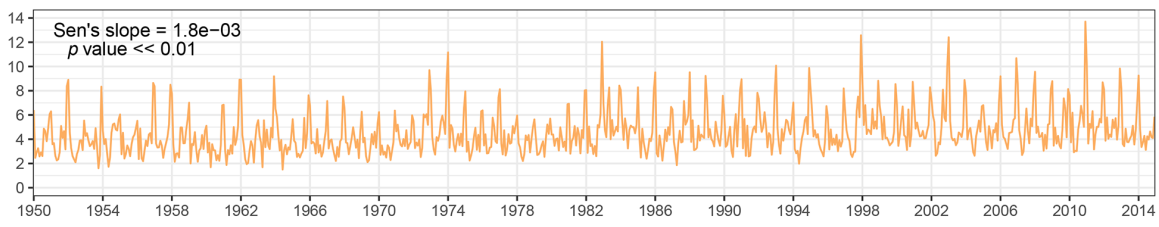

(h)

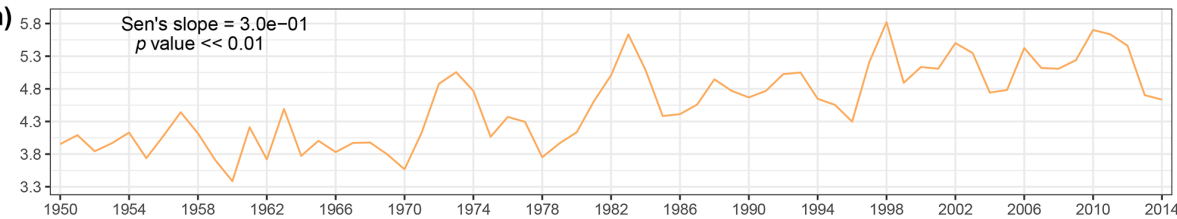

Time

Figure 1. Percentage (\%) of total land area with $(\mathbf{a}, \mathbf{b})$ wet (blue), (c, d) dry (red), (e, f) neutral (black), and (g, h) extreme wet + extreme dry (orange) events over the 1950-2014 period. Wet extreme events are computed from AMAX having sc_PDSI_pm $\geq 3$; dry extreme events from AMIN having sc_PDSI_pm $\leq-3$; neutral events from AMAX and AMIN having $-3<$ sc_PDSI_pm $<3$; and wet-dry extreme events by summing the areas of $(\mathbf{a}, \mathbf{b})$ and $(\mathbf{c}, \mathbf{d}) .(\mathbf{a}, \mathbf{c}, \mathbf{e}, \mathbf{g})$ The events at a monthly timescale and $(\mathbf{b}, \mathbf{d}, \mathbf{f}, \mathbf{h})$ the events aggregated and averaged over annual periods. Sen's slopes and the significance of the Mann-Kendall test ( $p$ values) are shown in each panel. 

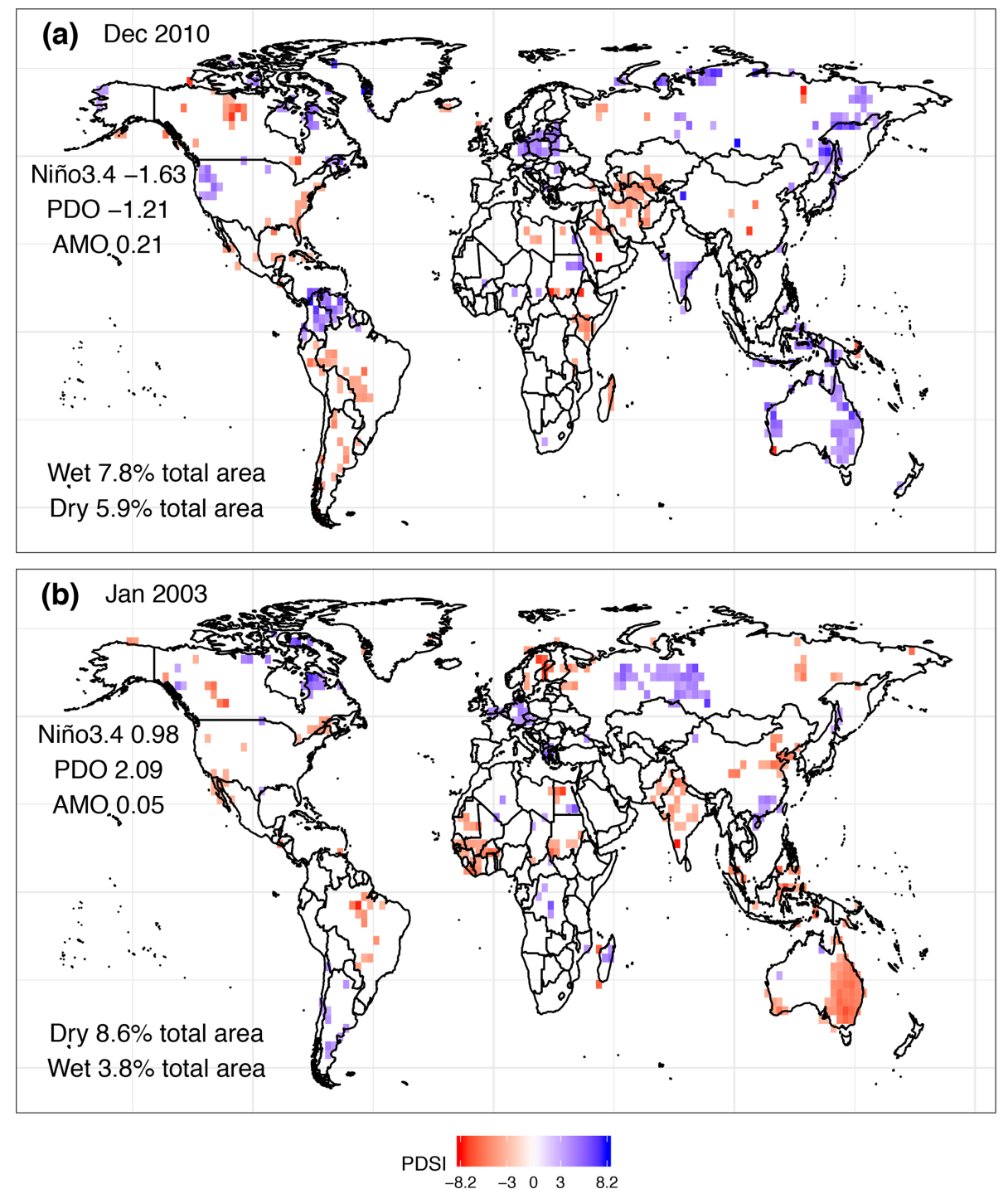

Figure 2. (a) The most widespread extreme global wet hydrological event (blue colour) and coincident extreme dry areas (red colour), December 2010. The event was also the most widespread concurrent wet-dry episode. The percentage (\%) of total land area is shown for both wet and dry extremes, along with the values of the three climate indices (i.e. Niño3.4, PDO, and AMO) in December 2010. Panel (b) is as panel (a) but for the most widespread extreme global dry hydrological event, January 2003. Only sc_PDSI_pm $\geq 3$ and sc_PDSI_pm $\leq-3$ values are plotted.

300 deaths and leaving thousands homeless (BBC, 2010b; Telegraph, 2010; Trenberth and Fasullo, 2012), and flooding affecting the north-western USA (NWRFC, 2010). We also find anomalously wet conditions in central-eastern Europe (Fig. 2a), although in this region no significant damage was reported by the literature and the media. Such a widespread wet event impacted $7.8 \%$ of the total global land area. December 2010 was characterized by a very strong negative Niño3.4 phase within the 2010-2012 La Niña event (Luo et al., 2017). Moreover, the PDO and AMO were respectively in their cold and positive phases. The same phases occurred during November 2010 (not shown), and these antecedent conditions may have contributed to the extreme wet and dry events in the sc_PDSI_pm series (Lee et al., 2018). At the same time, droughts were recorded in central Asia, Madagascar, the Horn of Africa (BBC, 2011), South America, the eastern USA (NOAA, 2011), and northern Canada, covering a total of $5.9 \%$ of land area. Both the extreme wet and dry percentages $(\%)$ of land area impacted (Fig. 2a) are significant at the $5 \%$ level ( $p$ value $<0.05$ ) according to our bootstrapping procedure (see Sect. 2.2).

The most widespread extreme dry hydrological event occurred during January 2003, with $8.6 \%$ of total land area impacted by drought and $3.8 \%$ of land experiencing wet hydrological extremes and floods (Fig. 2b). During this event, eastern Australia was the most affected region, with the worst 


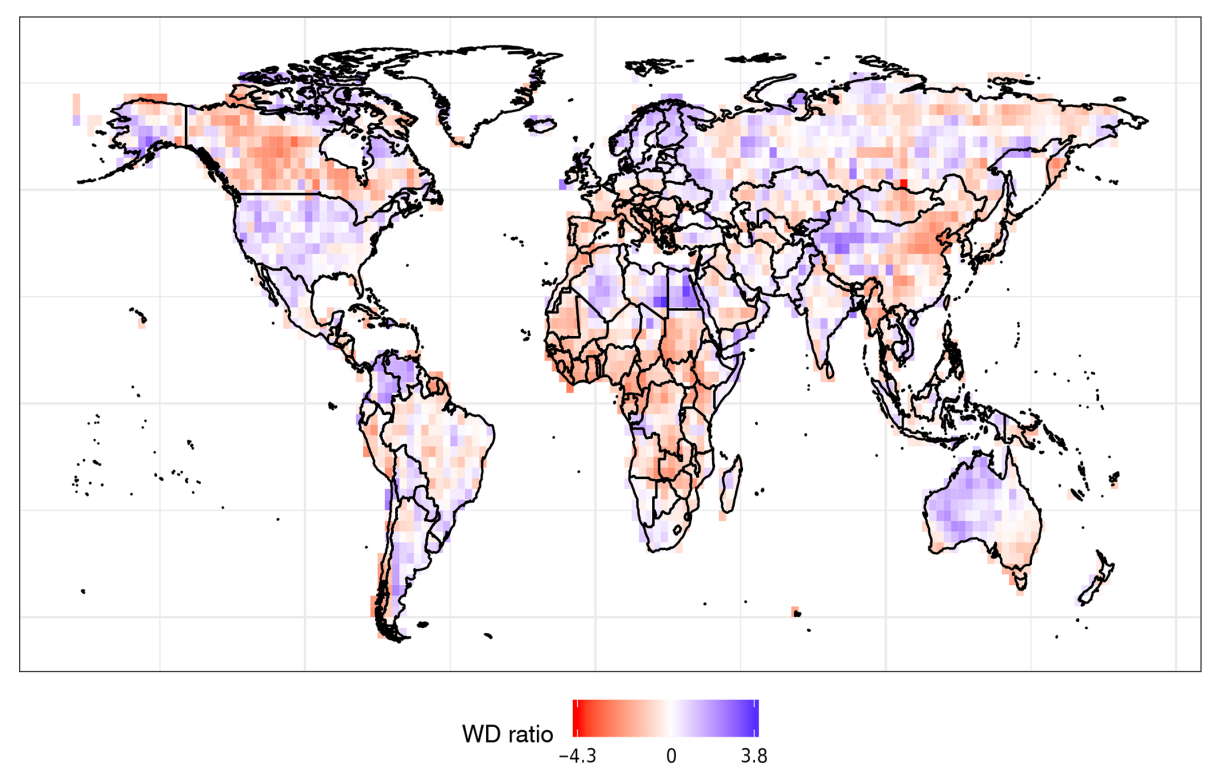

Figure 3. Wet-dry (WD) ratio derived for every grid cell. Blue (WD ratio $>0$ ) means that the area experienced more wet than dry hydrological extremes. Red (WD ratio $<0$ ) indicates the opposite.

drought in 20 years driven by an El Niño event that led to severe dust storms and bushfires (Gabric et al., 2010; Horridge et al., 2005; Levinson and Waple, 2004; McAlpine et al., 2007). This episode belongs to the so-called "millennium drought" (Van Dijk et al., 2013), which affected Australia between 2001 and 2009. Other regions experiencing severe drought during January 2003 were north-east China, India (Sinha et al., 2016), Scandinavia (Irannezhad et al., 2017), western Africa, parts of Brazil, and a few scattered areas in Mexico, the USA, Canada, Russia, and Indonesia. January 2003 was an El Niño month, with the Niño3.4 index being in a positive phase along with a warm PDO phase. On the other hand, the AMO registered an almost neutral phase. As for the December 2010 episode in Fig. 2a, such climate patterns also occurred in the previous month (not shown). Meanwhile, other regions experienced wet hydrological extremes and floods, such as south-east China, central Russia, Europe, southern Great Britain (BBC, 2003; Marsh, 2004), Madagascar (Reliefweb, 2003), Argentina, Chile, and scattered parts of Africa and Canada (DFO, 2008). As for Fig. 2a, the percentage of land area impacted by both extreme wet and dry events during January 2003 (Fig. 2b) was significantly different at the $5 \%$ level $(p$ value $<0.05)$ from the values expected by chance.

Moran's spatial correlation results are shown in Table 1. Wet and dry extremes in December 2010 (Fig. 2a) show $I=$ 0.24 ( $p$ value $<0.001$ ). Positive, statistically significant $I$ results are also obtained when considering wet and dry extremes individually $(I=0.04$ for wet extremes and $I=0.25$ for dry extremes, $p$ value $<0.001)$. For the events occurring during January 2003 (Fig. 2b) combined wet and dry extremes show $I=0.27$ ( $p$ value $<0.001$ ), and wet and dry
Table 1. Moran's $I$ correlation coefficients for wet and dry, wet, and dry hydrological extremes as in Fig. 2a and b.

\begin{tabular}{llccc}
\hline Event & Extremes & $\begin{array}{c}\text { Moran's } \\
I\end{array}$ & $\begin{array}{c}\text { Standard } \\
\text { deviation }\end{array}$ & $p$ value \\
\hline \multirow{3}{*}{ December 2010 } & wet and dry & 0.240 & 0.007 & $<0.001$ \\
& wet & 0.040 & 0.013 & $<0.001$ \\
& dry & 0.253 & 0.044 & $<0.001$ \\
\hline \multirow{2}{*}{ January 2003 } & wet and dry & 0.267 & 0.008 & $<0.001$ \\
& wet & 0.065 & 0.022 & $<0.001$ \\
& dry & 0.262 & 0.032 & $<0.001$ \\
\hline
\end{tabular}

extremes computed individually respectively have $I=0.07$ and $I=0.26$ ( $p$ values $<0.001)$. In other words, wet and dry hydrological extremes as both concurrent and independent hazards tend to occur in regions close to each other, with wet and dry as well as dry extremes showing greater levels of clustering (or $I$ ) values (Table 1). This reflects strong spatial coherence between wet and dry extremes such that a location neighbouring one experiencing drought is more likely to be very dry than very wet (Hannaford et al., 2011).

\subsection{Wet-dry (WD) ratio}

The WD ratio highlights the 65 -year propensity for more or less wet or dry hydrological extremes on a cell-by-cell basis (Fig. 3). Hotspots for extreme wet propensity emerge in the USA, northern Mexico, Colombia, Venezuela, Argentina, Bolivia, Paraguay, northern Europe, North Africa, western China, and western and central Australia. On the other hand, regions with higher frequencies of extreme dry events are 
found in Canada, central South America, central and southern Europe and Africa, eastern China, and south-eastern Australia. Other regions, such as Russia, display mixed patterns. These WD ratio patterns agree with global trends in drought over the period 1950-2010, identified using the sc_PDSI_pm dataset (Dai, 2012).

\subsection{Extreme transitions (ETs)}

In Fig. 4a we show the average time intervals (months) of extreme transitions (ETs) from wet-to-dry and dry-to-wet extremes during the period 1950-2014 plotted against the percentage of total global land area affected. The ET from wet to dry (blue curve) exhibits a modal value of 22 months, associated with $4.3 \%$ of the total global land area. On the other hand, ET from dry to wet (red curve) peaks at 18 months, with $\sim 5 \%$ of global land area having this average separation time. Overall, ET from wet to dry takes longer than ET from dry to wet. We also show the cumulative distribution functions (CDFs) of wet-to-dry and dry-to-wet ET time intervals (Fig. 4b). For wet to dry $50 \%$ of the ETs occur within $\sim 27$ months, whereas for dry to wet half of the ETs are observed within 21 months. The two ET medians are significantly different ( $p$ value $\ll 0.01$, two-sided MannWhitney-Wilcoxon test) (Mann and Whitney, 1947). The spatial distribution of the natural logarithm (ln) of ET means shows a homogeneous global pattern, without any major regional anomalies (Fig. S1 in the Supplement). The only noticeable large-scale feature is shorter dry-to-wet ET means over northern Africa (Fig. S1b). Figure 4 also shows a few ET $>150$ months, and these very long lags between wet (dry) and dry (wet) extremes occurred in different regions across the globe, namely Canada, Brazil, central and southern Africa, India, China, and Russia (Fig. S2). The reason behind such long ETs, which appear to be very localized (i.e. not clustered) events, may be due to precipitation biases in the sc_PDSI_pm dataset or to local geographical characteristics.

ETs from dry to dry and wet to wet were also computed (Fig. S3). Dry-to-dry time intervals peak at 27 months, with $3.2 \%$ of global land area taking this value, whereas wet-towet time intervals peak at 30 months with $3.1 \%$ of land area. Half of all dry-to-dry ETs occurred within $\sim 37$ months, whereas half of wet-to-wet ETs happen in $\sim 36$ months. A two-sided Mann-Whitney-Wilcoxon test shows that the two medians are significantly different $(p$ value $<0.01)$ as per the multi-hazards case.

\subsection{Correlations with climate indices}

In Fig. 5, we show global correlations between hydrological extremes (wet and dry) and three of the major modes of climate variability (Niño3.4, PDO, and AMO; see Sect. 2.4). We also computed the same correlation tests for the NAO (Barnston and Livezey, 1987), Pacific North Amer-

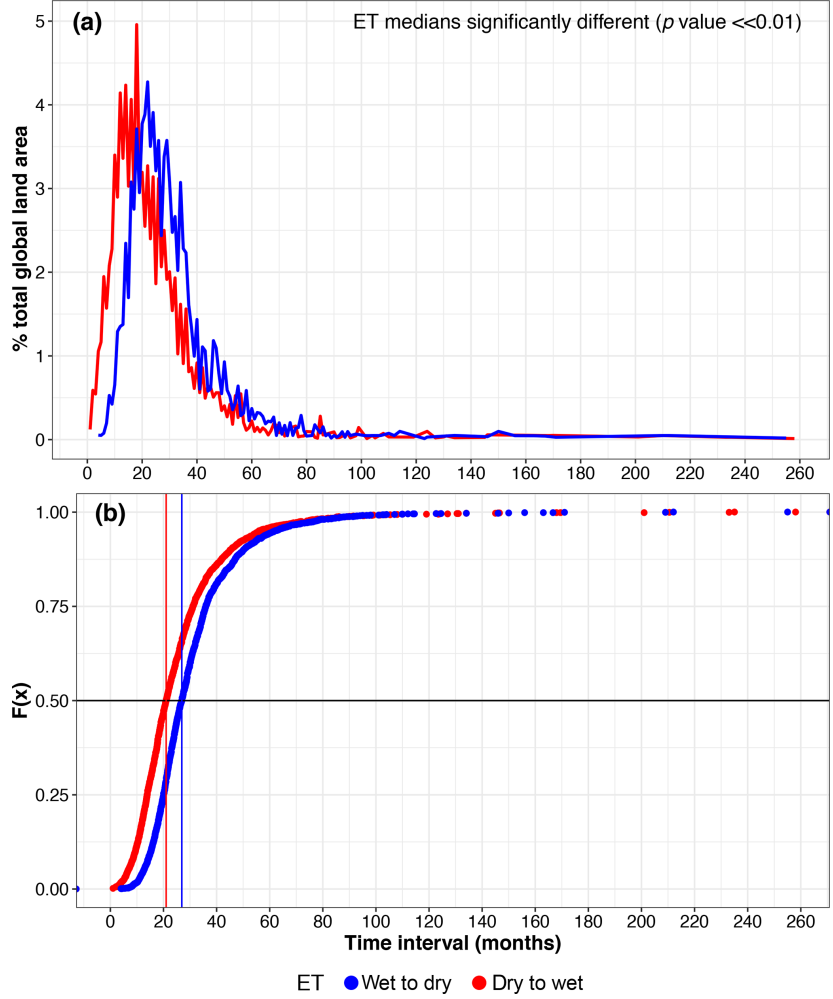

Figure 4. Extreme transition (ET) time intervals between extreme wet to dry (blue) and between extreme dry to wet (red). (a) Percentage $(\%)$ of total land area impacted as a function of ET and (b) cumulative distribution functions (CDFs). The vertical blue and red lines mark the medians of the distributions. The two distributions show a statistically significant difference in their medians ( $p$ value $\ll 0.01$, Mann-Whitney-Wilcoxon test).

ican (PNA) pattern (Barnston and Livezey, 1987), and Quasibiennial Oscillation (QBO) (Baldwin et al., 2001). However, these results had low statistical significance (Fig. S4). Generally, the correlations shown in Fig. 5 are consistent with the concurrent wet-dry spatial patterns observed in Fig. 2.

ENSO is one of the modes with the most widespread global impacts and is represented here by the Niño3.4 index (Fig. 5a). The positive phase of Niño3.4 (associated with El Niño events) is negatively correlated ( $p$ value $<0.05$ ) with extreme wet sc_PDSI_pm values over parts of central Canada, northern South America, southern Africa, India, central China, central and northern Russia, Indonesia, and eastern Australia. On the other hand, positive significant correlations are found over the southern USA, in some isolated regions of central and southern South America, and in the Middle East. Such correlation patterns can be explained as a positive Niño3.4 phase associated with wet extremes for which correlations are positive and with dry extremes for which correlations are negative (this also applies to the positive phase of the PDO and AMO discussed below). The percentage of total land area impacted by significant Niño3.4 

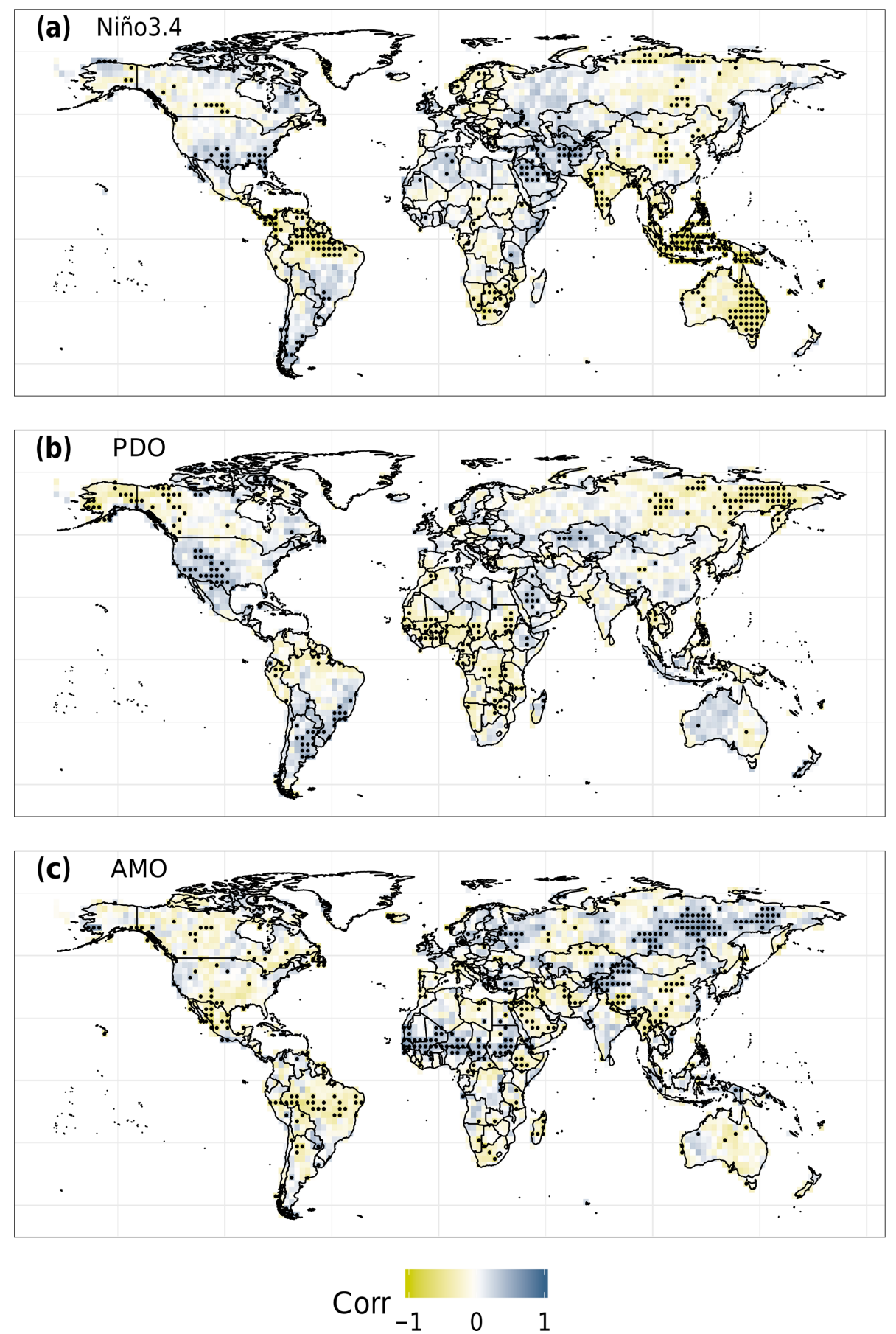

Figure 5. Correlations between monthly wet (sc_PDSI_pm $\geq 3$ ) and dry (sc_PDSI_pm $\leq-3$ ) hydrological extremes and (a) Niño3.4, (b) PDO, and (c) AMO. For panels (b) and (c) partial correlations are performed to remove the Niño3.4 signal. Correlations and partial correlations make use of the Spearman's correlation coefficient. Correlations significant at the $5 \%$ level $(p$ value $<0.05)$ are stippled. The Bonferroni correction was applied to all $p$ values.

correlations amounts to $18.1 \%$. These results agree with the wet and dry patterns linked to ENSO and PDO reported by Wang et al. (2014) for boreal winter (December-February).
Correlations for PDO (Fig. 5b, with the Niño3.4 signal removed) partly resemble the spatial patterns found for Niño3.4. Here, negative correlations are also found in northwestern North America, equatorial Africa, and eastern Russia, although most significant correlations over Australia, 
China, and India vanish. Moreover, positive correlations are found in the central-western USA, southern South America, and Kazakhstan. The fact that Niño3.4 and PDO correlations show similar spatial patterns (Fig. 5a and b) suggests that when these two indices are in phase (i.e. El Niño-warm PDO and La Niña-cold PDO), wet and dry extremes are amplified (Wang et al., 2014). The correlation patterns shown in Fig. 5b also agree with season-ahead peak river flow correlations with the PDO (Lee et al., 2018). The PDO significantly impacts a smaller area (12\% of total global land) compared to Niño3.4. Niño3.4 and PDO correlations also tend to resemble the WD ratio patterns (Fig. 3). For instance, we note that both Niño3.4 and PDO show positive rank correlations with the extreme sc_PDSI_pm over the southern and western USA (Fig. 5a and b), which are reflected by the predominance of wet extremes (over dry extremes) in Fig. 3. Similar patterns are also observed over south-eastern Brazil and Argentina. In addition, Fig. 5a and b show negative correlations with wet extremes over central and eastern Russia, a pattern matched by the predominance of dry extremes (over wet extremes) in Fig. 3. A similar coherence in patterns also applies to eastern Australia and central-southern Africa.

The pattern of AMO correlations (Fig. 5c, with the Niño3.4 signal removed) differs from the Niño3.4 and PDO indices and returns more significant $(p$ value $<0.05)$ grid cells $(2.5 \%$ more overall) and impacted area $(18.9 \%)$ than Niño3.4. For the AMO, negative and significant correlations are found in Brazil, Argentina, Mexico, scattered areas in North America, the Horn of Africa, and eastern China. Positive correlations are found in the Sahel region of Africa, Russia, and central Asia. Our results are again in agreement with global season-ahead correlations reported for peak river flows and the AMO (Lee et al., 2018). We also computed 1and 2-month lagged correlations between wet and dry hydrological extremes and Niño3.4, PDO, and AMO. The results are qualitatively similar to Fig. 5 (Figs. S5 and S6).

\section{Discussion and conclusions}

Wet and dry extremes can coincide in time and/or space, creating multi-hazard events that lead to significant socioeconomic losses. Geographically remote yet temporally coincident extremes potentially impact stakeholders with global assets and/or supply chains. For instance, knowledge of recurrent patterns of coincident hydrological extremes could be used to hedge losses in regional hydropower production (Ng et al., 2017; Turner et al., 2017) and agricultural yields (Leng and Hall, 2019; Xie et al., 2018; Zampieri et al., 2017) or to manage crop planting dates (Sacks et al., 2010). Rapid successions of extremes at the same location pose challenges for disaster preparedness, event management, and long-term risk reduction. Floods and droughts are also expected to become regionally more frequent and severe in the future due to anthropogenic climate change (Arnell and
Gosling, 2016; Dai, 2011a, 2012; Hirabayashi et al., 2013; Hirsch and Archfield, 2015; IPCC, 2012; Milly et al., 2002), underscoring the importance of research on concurrent wetdry hydrological extremes.

We found that the land area affected by extreme dry and geographically remote wet-dry events is increasing, with statistically significant trends at both monthly and annual timescales (Fig. 1). This matches the expectation that such hazards are likely to increase in the future (Güneralp et al., 2015; Hirabayashi et al., 2013) and is in agreement with previous studies (Dai, 2012; Dai et al., 2004). However, we applied a more stringent definition of extreme events (De Luca et al., 2017) in order to capture well-known flood and drought episodes. We further showed that these extremes can have global-scale impacts, corresponding to documented flooding and drought events, by detecting the most widespread wet, dry, and wet-dry events (Fig. 2). As a limitation of our study, we recognize that the coarse horizontal resolution of the dataset used (sc_PDSI_pm at $2.5^{\circ}$ ) may not sufficiently represent small-scale processes such as localized convective precipitation events.

We introduced two new metrics: the wet-dry (WD) ratio (Figs. 3 and S1-S2) and the average time between extreme transitions (ETs) for wet-to-dry and dry-to-wet extremes (Fig. 4). The former reveals the local frequency of extreme wet relative to extreme dry observations. Areas experiencing more wet than dry extremes were detected in the USA, northern and southern South America, northern Europe and North Africa, western China, and most of Australia. More dry than wet extremes were experienced in most of the remaining areas. The ET metric estimates for every grid cell the average time interval between opposing extremes (i.e. transitions from wet to dry and from dry to wet). The median time between wet-to-dry transitions is on average slower than the one between dry to wet. Monitoring longterm changes in ET intervals between wet-to-dry and dry-towet hydrological extremes could provide valuable information on loss accrual and socio-economic impacts.

To this end, it is important to identify possible climate drivers of the observed hydrological extremes. In this study, we computed correlations between wet-dry hydrological extremes and corresponding values of the Niño3.4, PDO, and AMO indices (Figs. 5 and S5-S6). Our results confirm previous findings about the effect of ENSO, PDO, and AMO on global flood hazard and global season-ahead correlations with river peak flows (Emerton et al., 2017; Hodgkins et al., 2017; Lee et al., 2018; Mallakpour and Villarini, 2015; Tootle et al., 2005; Wang et al., 2014; Ward et al., 2010, 2014), while presenting a useful tool for interpreting the most widespread wet-dry events and WD ratio and ET metrics. PDO spatial correlations with hydrological extremes generally match those of Niño3.4, which supports the view that when Niño3.4and PDO are in phase they amplify the global wet and dry changes (Wang et al., 2014). Niño3.4 and PDO correlations also tend to reflect the patterns found for the 
WD ratio. In other words, when Niño3.4 and PDO are in a positive (negative) phase this leads to extreme wet and dry conditions in some regions, and these wet-dry patterns also occur in areas which have in the past respectively experienced more wet-dry conditions. The AMO shows different, and in some cases opposite, correlation patterns when compared to Niño3.4 and the PDO. During the most widespread wet, dry, and wet-dry hydrological extremes, the AMO was weak, and indeed the geographical footprint of these events does not closely match that of the AMO. Hence, we assert that the most widespread wet and wet-dry (dry) hydrological extreme events were driven by a La Niña (El Niño) event coupled with a strong negative (positive) PDO phase. However, we note that modes of climate variability cannot entirely explain the physical mechanisms driving these multihazard events. Indeed, when selecting similar phase values of the Niño3.4, PDO, and AMO indices occurring during the most widespread events (Fig. 2), it is not possible to recover similar events in terms of overall impacted areas (Figs. S7 and S8).

The analysis was conducted using the self-calibrated monthly mean Palmer Drought Severity Index based on the Penman-Monteith model (Dai, 2017; Sheffield et al., 2012). Future research opportunities include using other indices, such as the Standardized Precipitation Index (McKee et al., 1993, 1995) or the Standardized Precipitation Evapotranspiration Index (Vicente-Serrano et al., 2010), to validate our findings and to account for uncertainty in the observations of concurrent wet-dry extremes. Additionally, there is scope to use more recently developed soil moisture metrics emerging from the ESA Soil Moisture CCI Project (Gruber et al., 2019) and the NASA Soil Moisture Active Passive (SMAP) mission (https://smap.jpl.nasa.gov/, last access: 6 March 2020). These datasets have finer spatio-temporal resolution (such as daily at $0.25^{\circ}$ for ESA CCI), thus possibly providing more detailed information about local concurrent wet-dry extremes. Unfortunately, these are not long enough for trend analysis (e.g. NASA SMAP data begin in 2015). Further work is needed to evaluate the seasonality of the extremes linked to the modes of climate variability investigated in this work, but also to other ones, such as the Indian Ocean Dipole (IOD) (Saji et al., 1999), which has recently been associated with concurrent floods and bushfires, respectively, in eastern Africa and Australia (BBC, 2019). Similar analyses could be applied to individual Köppen climate zones (Rubel and Kottek, 2010) to discern possible regional variations in concurrent wet-dry extreme characteristics. Finally, once baseline maps and data for hydrological multi-hazards have been established from observations, the next step should be to use climate model output to evaluate how global patterns of concurrent wet-dry extremes might change in the future.
Data availability. The sc_PDSI_pm dataset is freely available from Dai (2017) https://doi.org/10.5065/D6QF8R93.

Supplement. The supplement related to this article is available online at: https://doi.org/10.5194/esd-11-251-2020-supplement.

Author contributions. PDL conceived the methods, performed the analyses, created the figures, and wrote the first paper draft. GM and RW contributed to the methods. All the authors contributed to the writing.

Competing interests. The authors declare that they have no conflict of interest.

Special issue statement. This article is part of the special issue "Hydro-climate dynamics, analytics and predictability". It is not associated with a conference.

Acknowledgements. The authors would like to thank the two anonymous reviewers and the editor for their constructive comments. Paolo De Luca would also like to thank Venugopal Thandlam for the useful discussions and comments.

Financial support. This research has been supported by CENTA NERC (UK) (grant no. NE/L002493/1) and the Swedish Research Council Vetenskapsrådet (grant no. 2016-03724).

Review statement. This paper was edited by Valerio Lucarini and reviewed by two anonymous referees.

\section{References}

Alfieri, L., Feyen, L., and Di Baldassarre, G.: Increasing flood risk under climate change: a pan-European assessment of the benefits of four adaptation strategies, Climatic Change, 136, 507-521, https://doi.org/10.1007/s10584-016-1641-1, 2016.

Arnell, N. W. and Gosling, S. N.: The impacts of climate change on river flood risk at the global scale, Climatic Change, 134, 387401, https://doi.org/10.1007/s10584-014-1084-5, 2016.

Baldwin, M. P., Gray, L. J., Dunkerton, T. J., Hamilton, K., Haynes, P. H., Randel, W. J., Holton, J. R., Alexander, M. J., Hirota, I., Horinouchi, T., Jones, D. B. A., Kinnersley, J. S., Marquardt, C., Sato, K., and Takahashi, M.: The quasi-biennial oscillation, Rev. Geophys., 39, 179-229, https://doi.org/10.1029/1999RG000073, 2001.

Barnston, A. G. and Livezey, R. E.: Classification, Seasonality and Persistence of Low-Frequency Atmospheric Circulation Patterns, Mon. Weather Rev., 115, 1083-1126, https://doi.org/10.1175/15200493(1987)115<1083:CSAPOL>2.0.CO;2, 1987. 
Barredo, J. I.: Major flood disasters in Europe: 1950-2005, Nat. Hazards, 42, 125-148, https://doi.org/10.1007/s11069-0069065-2, 2007.

BBC: Floods bring miserable start to 2003, available at: http://news. bbc.co.uk/1/hi/uk/2623729.stm (last access: 6 March 2020), 2003

BBC: Horn of Africa sees "worst drought in 60 years", available at: https://www.bbc.co.uk/news/world-africa-13944550 (last access: 6 March 2020), 2011.

BBC: Australia: Queensland floods spur more evacuations, available at: https://www.bbc.co.uk/news/ world-asia-pacific-12097280 (last access: 6 March 2020), 2010a.

BBC: Colombia flooding continues with thousands homeless, available at: https://www.bbc.co.uk/news/ world-latin-america-12006568 (last access: 6 March 2020), 2010b.

BBC: Indian Ocean Dipole: What is it and why is it linked to floods and bushfires?, available at: https://www.bbc.com/news/ science-environment-50602971 (last access: 6 March 2020), 2019.

Berton, R., Driscoll, C. T., and Adamowski, J. F.: The near-term prediction of drought and flooding conditions in the northeastern United States based on extreme phases of AMO and NAO, J. Hydrol., 553, 130-141, https://doi.org/10.1016/j.jhydrol.2017.07.041, 2017.

Bonferroni, C.: Teoria statistica delle classi e calcolo delle probabilita, Pubbl. del R Ist. Super. di Sci. Econ. e Commericiali di Firenze, 8, 3-62, 1936.

Byrne, M. P. and O'Gorman, P. A.: The Response of Precipitation Minus Evapotranspiration to Climate Warming: Why the "WetGet-Wetter, Dry-Get-Drier" Scaling Does Not Hold over Land, J. Climate, 28, 8078-8092, https://doi.org/10.1175/JCLI-D-150369.1, 2015.

Cai, W. and Rensch, P.: The 2011 southeast Queensland extreme summer rainfall: A confirmation of a negative Pacific Decadal Oscillation phase?, Geophys. Res. Lett., 39, L08702, https://doi.org/10.1029/2011GL050820, 2012.

Chen, T., Zhang, H., Chen, X., Hagan, D. F., Wang, G., Gao, Z., and Shi, T.: Robust drying and wetting trends found in regions over China based on Köppen climate classifications, J. Geophys. Res.-Atmos., 122, 4228-4237, https://doi.org/10.1002/2016JD026168, 2017.

Collet, L., Harrigan, S., Prudhomme, C., Formetta, G., and Beevers, L.: Future hot-spots for hydro-hazards in Great Britain: a probabilistic assessment, Hydrol. Earth Syst. Sci., 22, 5387-5401, https://doi.org/10.5194/hess-22-5387-2018, 2018.

Corder, G. W. and Foreman, D. I.: Nonparametric Statistics: A Stepby-Step Approach, Wiley, Hoboken, New Jersey, USA, 2014.

Dai, A., Trenberth, K. E., and Qian, T.: A Global Dataset of Palmer Drought Severity Index for 1870-2002: Relationship with Soil Moisture and Effects of Surface Warming, J. Hydrometeorol., 5, 1117-1130, https://doi.org/10.1175/JHM-386.1, 2004.

Dai, A.: Drought under global warming: A review, Wiley Interdiscip. Rev. Clim. Change, 2, 45-65, https://doi.org/10.1002/wcc.81, 2011a.

Dai, A.: Characteristics and trends in various forms of the Palmer Drought Severity Index during 1900-2008, J. Geophys. Res.-
Atmos., 116, D12115, https://doi.org/10.1029/2010JD015541, 2011b.

Dai, A.: Increasing drought under global warming in observations and models, Nat. Clim. Change, 3, 52-58, https://doi.org/10.1038/nclimate1633, 2012.

Dai, A.: Dai Global Palmer Drought Severity Index (PDSI), Research Data Archive at the National Center for Atmospheric Research, Computational and Information Systems Laboratory, https://doi.org/10.5065/D6QF8R93, 2017.

Deangelis, R. J., Urban, J. B., Gburek, W. J., and Contino, M. A.: Precipitation and runoff on eight New England basins during extreme wet and dry periods, Hydrolog. Sci. J., 29, 13-28, https://doi.org/10.1080/02626668409490919, 1984.

De Luca, P., Hillier, J. K., Wilby, R. L., Quinn, N. W., and Harrigan, S.: Extreme multi-basin flooding linked with extra-tropical cyclones, Environ. Res. Lett., 12, 114009, https://doi.org/10.1088/1748-9326/aa868e, 2017.

De Luca, P., Messori, G., Pons, F. M. E., and Faranda, D.: Dynamical Systems Theory Sheds New Light on Compound Climate Extremes in Europe and Eastern North America, Q. J. Roy. Meteorol. Soc., https://doi.org/10.1002/qj.3757, in press, 2020.

DFO: Dartmouth Flood Observatory, Global Active Archive of Large Flood Events, available at: http://www.dartmouth.edu/ floods/Archives/2003sum.htm (last access: 6 March 2020), 2008.

Di Baldassarre, G., Montanari, A., Lins, H., Koutsoyiannis, D., Brandimarte, L., and Blöschl, G.: Flood fatalities in Africa: From diagnosis to mitigation, Geophys. Res. Lett., 37, L22402, https://doi.org/10.1029/2010GL045467, 2010.

Di Baldassarre, G., Martinez, F., Kalantari, Z., and Viglione, A.: Drought and flood in the Anthropocene: feedback mechanisms in reservoir operation. Earth Syst. Dynam., 8, 225-233, https://doi.org/10.5194/esd-8-225-2017, 2017.

Emerton, R., Cloke, H. L., Stephens, E. M., Zsoter, E., Woolnough, S. J., and Pappenberger, F.: Complex picture for likelihood of ENSO-driven flood hazard, Nat. Commun., 8, 14796, https://doi.org/10.1038/ncomms14796, 2017.

Forzieri, G., Feyen, L., Russo, S., Vousdoukas, M., Alfieri, L., Outten, S., Migliavacca, M., Bianchi, A., Rojas, R., and Cid, A.: Multi-hazard assessment in Europe under climate change, Climatic Change, 137, 105-119, https://doi.org/10.1007/s10584016-1661-x, 2016.

Gabric, A. J., Cropp, R. A., McTainsh, G. H., Johnston, B. M., Butler, H., Tilbrook, B., and Keywood, M.: Australian dust storms in 2002-2003 and their impact on Southern Ocean biogeochemistry, Global Biogeochem. Cy., 24, GB2005, https://doi.org/10.1029/2009GB003541, 2010.

Gallina, V., Torresan, S., Critto, A., Sperotto, A., Glade, T., and Marcomini, A.: A review of multi-risk methodologies for natural hazards: Consequences and challenges for a climate change impact assessment, J. Environ. Manage., 168, 123-132, 2016.

Gil-Guirado, S., Espín-Sánchez, J.-A., and Del Rosario Prieto, M.: Can we learn from the past? Four hundred years of changes in adaptation to floods and droughts. Measuring the vulnerability in two Hispanic cities, Climatic Change, 139, 183-200, https://doi.org/10.1007/s10584-016-1768-0, 2016.

Gill, J. C. and Malamud, B. D.: Reviewing and visualizing the interactions of natural hazards, Rev. Geophys., 52, 680-722, https://doi.org/10.1002/2013RG000445, 2014. 
Gruber, A., Scanlon, T., van der Schalie, R., Wagner, W., and Dorigo, W.: Evolution of the ESA CCI Soil Moisture climate data records and their underlying merging methodology, Earth Syst. Sci. Data, 11, 717-739, https://doi.org/10.5194/essd-11717-2019, 2019.

Güneralp, B., Güneralp, İ., and Liu, Y.: Changing global patterns of urban exposure to flood and drought hazards, Global Environ. Change, 31, 217-225, https://doi.org/10.1016/j.gloenvcha.2015.01.002, 2015.

Hannaford, J., Lloyd-Hughes, B., Keef, C., Parry, S., and Prudhomme, C.: Examining the large-scale spatial coherence of European drought using regional indicators of precipitation and streamflow deficit, Hydrol. Process., 25, 1146-1162, https://doi.org/10.1002/hyp.7725, 2011.

Hirabayashi, Y., Mahendran, R., Koirala, S., Konoshima, L., Yamazaki, D., Watanabe, S., Kim, H., and Kanae, S.: Global flood risk under climate change, Nat. Clim. Change, 3, 816-821, https://doi.org/10.1038/nclimate1911, 2013.

Hirsch, R. M. and Archfield, S. A.: Not higher but more often, Nat. Clim. Change, 5, 198-199, https://doi.org/10.1038/nclimate2551, 2015.

Hodgkins, G. A., Whitfield, P. H., Burn, D. H., Hannaford, J., Renard, B., Stahl, K., Fleig, A. K., Madsen, H., Mediero, L., Korhonen, J., Murphy, C., and Wilson, D.: Climatedriven variability in the occurrence of major floods across North America and Europe, J. Hydrol., 552, 704-717, https://doi.org/10.1016/j.jhydrol.2017.07.027, 2017.

Horridge, M., Madden, J., and Wittwer, G.: The impact of the 2002-2003 drought on Australia, J. Policy Model., 27, 285-308, https://doi.org/10.1016/j.jpolmod.2005.01.008, 2005.

IPCC: Managing the Risks of Extreme Events and Disasters to Advance Climate Change Adaptation, in: A Special Report of Working Groups I and II of the Intergovernmental Panel on Climate Change. Cambridge University Press, Cambridge, UK, and New York, NY, USA, https://doi.org/10.1017/CBO9781139177245, 2012.

Irannezhad, M., Ahmadi, B., Kløve, B., and Moradkhani, H.: Atmospheric circulation patterns explaining climatological drought dynamics in the boreal environment of Finland, 1962-2011, Int. J. Climatol., 37, 801-817, https://doi.org/10.1002/joc.5039, 2017.

Jonkman, S. N.: Global perspectives on loss of human life caused by floods, Nat. Hazards, 34, 151-175, https://doi.org/10.1007/s11069-004-8891-3, 2005.

Kappes, M. S., Keiler, M., von Elverfeldt, K., and Glade, T.: Challenges of analyzing multi-hazard risk: a review, Nat. Hazards, 64, 1925-1958, https://doi.org/10.1007/s11069-012-0294-2, 2012.

Kargel, J. S., Leonard, G. J., Shugar, D. H., Haritashya, U. K., Bevington, A., Fielding, E. J., Fujita, K., Geertsema, M., Miles, E. S., Steiner, J., Anderson, E., Bajracharya, S., Bawden, G. W., Breashears, D. F., Byers, A., Collins, B., Dhital, M. R., Donnellan, A., Evans, T. L., Geai, M. L., Glasscoe, M. T., Green, D., Gurung, D. R., Heijenk, R., Hilborn, A., Hudnut, K., Huyck, C., Immerzeel, W. W., Liming, J., Jibson, R., Kääb, A., Khanal, N. R., Kirschbaum, D., Kraaijenbrink, P. D. A., Lamsal, D., Shiyin, L., Mingyang, L., McKinney, D., Nahirnick, N. K., Zhuotong, N., Ojha, S., Olsenholler, J., Painter, T. H., Pleasants, M., Pratima, K. C., Yuan, Q. I., Raup, B. H., Regmi, D., Rounce, D. R., Sakai, A., Donghui, S., Shea, J. M., Shrestha, A. B., Shukla,
A., Stumm, D., van der Kooij, M., Voss, K., Xin, W., Weihs, B., Wolfe, D., Lizong, W., Xiaojun, Y., Yoder, M. R., and Young, N.: Geomorphic and geologic controls of geohazards induced by Nepal's 2015 Gorkha earthquake, Science, 351, aac8353, https://doi.org/10.1126/science.aac8353, 2016.

Kendall, M.: Multivariate analysis, Griffin, London, 1975.

Kim, S.: ppcor: An R Package for a Fast Calculation to Semi-partial Correlation Coefficients, Commun. Stat. Appl. Meth., 22, 665674, https://doi.org/10.5351/CSAM.2015.22.6.665, 2015.

Lee, D., Ward, P., and Block, P.: Attribution of LargeScale Climate Patterns to Seasonal Peak-Flow and Prospects for Prediction Globally, Water Resour. Res., 54, 916-938, https://doi.org/10.1002/2017WR021205, 2018.

Leng, G. and Hall, J.: Crop yield sensitivity of global major agricultural countries to droughts and the projected changes in the future, Sci. Total Environ., 654, 811-821, https://doi.org/10.1016/j.scitotenv.2018.10.434, 2019.

Levinson, D. H. and Waple, A. M.: State Of The Climate In 2003, B. Am. Meteorol. Soc., 85, S1-S72, 2004.

Li, H., Calder, C. A., and Cressie, N.: Beyond Moran's I: Testing for Spatial Dependence Based on the Spatial Autoregressive Model, Geogr. Anal., 39, 357-375, https://doi.org/10.1111/j.1538-4632.2007.00708.x, 2007.

Luo, J.-J., Liu, G., Hendon, H., Alves, O., and Yamagata, T.: Inter-basin sources for two-year predictability of the multiyear La Niña event in 2010-2012, Sci. Rep., 7, 2276, https://doi.org/10.1038/s41598-017-01479-9, 2017.

Mallakpour, I. and Villarini, G.: The changing nature of flooding across the central United States, Nat. Clim. Change, 5, 250-254, https://doi.org/10.1038/nclimate2516, 2015.

Mann, H. B.: Nonparametric Tests Against Trend, Econometrica, 13, 245-259, https://doi.org/10.2307/1907187, 1945.

Mann, H. B. and Whitney, D. R.: On a Test of Whether one of Two Random Variables is Stochastically Larger than the Other, Ann. Math. Stat., 18, 50-60, https://doi.org/10.1214/aoms/1177730491, 1947.

Mantua, N. J. and Hare, S. R.: The Pacific Decadal Oscillation, J. Oceanogr., 58, 35-44, https://doi.org/10.1023/A:1015820616384, 2002.

Marsh, T. J.: The January 2003 flood on the Thames, Weather, 59, 59-62, https://doi.org/10.1256/wea.212.03, 2004.

Martin, E. R.: Future Projections of Global Pluvial and Drought Event Characteristics, Geophys. Res. Lett., 45, 11913-13920, https://doi.org/10.1029/2018GL079807, 2018.

Marvel, K., Cook, B. I., Bonfils, C. J. W., Durack, P. J., Smerdon, J. E., and Williams, A. P.: Twentieth-century hydroclimate changes consistent with human influence, Nature, 569, 59-65, https://doi.org/10.1038/s41586-019-1149-8, 2019.

McAlpine, C. A., Syktus, J., Deo, R. C., Lawrence, P. J., McGowan, H. A., Watterson, I. G., and Phinn, S. R.: Modeling the impact of historical land cover change on Australia's regional climate, Geophys. Res. Lett., 34, L22711, https://doi.org/10.1029/2007GL031524, 2007.

McKee, T. B., Doesken, N. J., and Kleist, J.: The relationship of drought frequency and duration to time scales, in: AMS 8th Conf. Appl. Climatol., 17-22 January 1993, Anaheim, California, USA, 179-184, 1993. 
McKee, T. B., Doesken N. J., and Kleist, J.: Drought monitoring with multiple time scales, in: Proc. 9th Conf. Appl. Climatol., 15-20 January 1995, Dallas, Texas, USA, 233-236, 1995.

Milly, P. C. D., Wetherald, R. T., Dunne, K. A., and Delworth, T. L.: Increasing risk of great floods in a changing climate, Nature, 415, 514-517, https://doi.org/10.1038/415514a, 2002.

Moran, P. A. P.: Notes on Continuous Stochastic Phenomena, Biometrika, 37, 17-23, https://doi.org/10.2307/2332142, 1950.

Naumann, G., Spinoni, J., Vogt, J. V., and Barbosa, P.: Assessment of drought damages and their uncertainties in Europe, Environ. Res. Lett., 10, 124013, https://doi.org/10.1088/17489326/10/12/124013, 2015.

Ng, J. Y., Turner, S. W. D., and Galelli, S.: Influence of El Niño Southern Oscillation on global hydropower production, Environ. Res. Lett., 12, 34010, https://doi.org/10.1088/1748-9326/aa5ef8, 2017.

NOAA: State of the Climate: Drought for December 2010, available at: https://www.ncdc.noaa.gov/sotc/drought/201012 (last access: 6 March 2020), 2011.

Nobre, G. G., Jongman, B., Aerts, J., and Ward, P. J.: The role of climate variability in extreme floods in Europe, Environ. Res. Lett., 12, 84012, https://doi.org/10.1088/1748-9326/aa7c22, 2017.

NWRFC: 2010 Northwest Floods, available at: https://www.nwrfc. noaa.gov/floods/dec_2010/2010_Northwest_Flood.pdf (last access: 6 March 2020), 2010.

Oni, S., Futter, M., Ledesma, J., Teutschbein, C., Buttle, J., and Laudon, H.: Using dry and wet year hydroclimatic extremes to guide future hydrologic projections, Hydrol. Earth Syst. Sci., 20, 2811-2825, https://doi.org/10.5194/hess-20-2811-2016, 2016.

Orlowsky, B. and Seneviratne, S. I.: Elusive drought: uncertainty in observed trends and short- and long-term CMIP5 projections, Hydrol. Earth Syst. Sci., 17, 1765-1781, https://doi.org/10.5194/hess-17-1765-2013, 2013.

Palmer, W.: Meteorological Drought, US Res. Pap. No. 45, US Weather Bur., Washington, D.C., 1965.

Parry, S., Marsh, T., and Kendon, M.: 2012: From drought to floods in England and Wales, Weather, 68, 268-274, 2013.

Pechlivanidis, I. G., Arheimer, B., Donnelly, C., Hundecha, Y., Huang, S., Aich, V., Samaniego, L., Eisner, S., and Shi, P.: Analysis of hydrological extremes at different hydro-climatic regimes under present and future conditions, Climatic Change, 141, 467481, https://doi.org/10.1007/s10584-016-1723-0, 2017.

Quesada-Montano, B., Di Baldassarre, G., Rangecroft, S., and Van Loon, A. F.: Hydrological change: Towards a consistent approach to assess changes on both floods and droughts, Adv. Water Resour., 111, 31-35, https://doi.org/10.1016/j.advwatres.2017.10.038, 2018.

Rayner, N. A., Parker, D. E., Horton, E. B., Folland, C. K., Alexander, L. V., Rowell, D. P., Kent, E. C., and Kaplan, A.: Global analyses of sea surface temperature, sea ice, and night marine air temperature since the late nineteenth century, J. Geophys. Res.-Atmos., 108, 4407, https://doi.org/10.1029/2002JD002670, 2003.

Reliefweb: Madagascar: Floods - Jan 2003, available at: https://reliefweb.int/disaster/fl-2003-0037-mdg (last access: 6 March 2020), 2003.

Reliefweb: India: Floods - Dec 2010, available at: https://reliefweb. int/disaster/fl-2010-000249-ind (last access: 6 March 2020), 2010 .
Rubel, F. and Kottek, M.: Observed and projected climate shifts 1901-2100 depicted by world maps of the KöppenGeiger climate classification, Meteorol. Z., 19, 135-141, https://doi.org/10.1127/0941-2948/2010/0430, 2010.

Sacks, W. J., Deryng, D., Foley, J. A., and Ramankutty, N.: Crop planting dates: an analysis of global patterns, Global Ecol. Biogeogr., 19, 607-620, https://doi.org/10.1111/j.14668238.2010.00551.x, 2010.

Saji, N. H., Goswami, B. N., Vinayachandran, P. N., and Yamagata, T.: A dipole mode in the tropical Indian Ocean, Nature, 401, 360 363, https://doi.org/10.1038/43854, 1999.

Schlesinger, M. E. and Ramankutty, N.: An oscillation in the global climate system of period 65-70 years, Nature 367, 723-726, https://doi.org/10.1038/367723a0, 1994.

Sedgwick, P.: Multiple hypothesis testing and Bonferroni's correction, BMJ Br. Med. J., 349, g6284, https://doi.org/10.1136/bmj.g6284, 2014.

Sen, P. K.: Estimates of the Regression Coefficient Based on Kendall's Tau, J. Am. Stat. Assoc., 63, 1379-1389, https://doi.org/10.1080/01621459.1968.10480934, 1968.

Sheffield, J., Wood, E. F., and Roderick, M. L.: Little change in global drought over the past 60 years, Nature, 491, 435-438, https://doi.org/10.1038/nature11575, 2012.

Siegert, F., Ruecker, G., Hinrichs, A., and Hoffmann, A. A.: Increased damage from fires in logged forests during droughts caused by El Niño, Nature, 414, 437-440, https://doi.org/10.1038/35106547, 2001.

Sinha, D., Syed, T. H., Famiglietti, J. S., Reager, J. T., and Thomas, R. C.: Characterizing Drought in India Using GRACE Observations of Terrestrial Water Storage Deficit, J. Hydrometeorol., 18, 381-396, https://doi.org/10.1175/JHM-D-16-0047.1, 2016.

Smith, J. K. G., Young, M. M., Wilson, K. L., and Craig, S. B.: Leptospirosis following a major flood in Central Queensland, Australia, Epidemiol. Infect., 141, 585-590, 2013.

Sun, Q., Miao, C., AghaKouchak, A., and Duan, Q.: Century-scale causal relationships between global dry/wet conditions and the state of the Pacific and Atlantic Oceans, Geophys. Res. Lett., 43, 6528-6537, https://doi.org/10.1002/2016GL069628, 2016.

Telegraph: Floods devastate Colombia and Venezuela, available at: https://www.telegraph.co.uk/news/worldnews/southamerica/ colombia/8186408/Floods-devastate-Colombia-and-Venezuela. html (last access: 6 March 2020), 2010.

Terzi, S., Torresan, S., Schneiderbauer, S., Critto, A., Zebisch, M., and Marcomini, A.: Multi-risk assessment in mountain regions: A review of modelling approaches for climate change adaptation, J. Environ. Manage., 232, 759-771, https://doi.org/10.1016/j.jenvman.2018.11.100, 2019.

Tootle, G. A., Piechota, T. C., and Singh, A.: Coupled oceanicatmospheric variability and U.S. streamflow, Water Resour. Res., 41, W12408, https://doi.org/10.1029/2005WR004381, 2005.

Trenberth, K. E.: The Definition of El Niño, B. Am. Meteorol. Soc., 78, 2771-2778, 1997.

Trenberth, K. E. and Fasullo, J. T.: Climate extremes and climate change: The Russian heat wave and other climate extremes of 2010, J. Geophys. Res.-Atmos., 117, D17103, https://doi.org/10.1029/2012JD018020, 2012.

Turner, S. W. D., Hejazi, M., Kim, S. H., Clarke, L., and Edmonds, J.: Climate impacts on hydropower and consequences for global 
electricity supply investment needs, Energy, 141, 2081-2090, https://doi.org/10.1016/j.energy.2017.11.089, 2017.

UNISDR: Sendai Framework for Disaster Risk Reduction 20152030, in: Third World Conf. Disaster Risk Reduction, 1418 March 2015, Sendai, Japan, 1-25, available at: https://www. preventionweb.net/files/43291_sendaiframeworkfordrren.pdf (last access: 6 March 2020), 2015.

Van Dijk, A. I. J. M., Beck, H. E., Crosbie, R. S., De Jeu, R. A. M., Liu, Y. Y., Podger, G. M., Timbal, B., and Viney, N. R.: The Millennium Drought in southeast Australia (2001-2009): Natural and human causes and implications for water resources, ecosystems, economy, and society, Water Resour. Res., 49, 1040-1057, https://doi.org/10.1002/wrcr.20123, 2013.

Van Loon, A. F., Gleeson, T., Clark, J., Van Dijk, A. I. J. M., Stahl, K., Hannaford, J., Di Baldassarre, G., Teuling, A. J., Tallaksen, L. M., Uijlenhoet, R., Hannah, D. M., Sheffield, J., Svoboda, M., Verbeiren, B., Wagener, T., Rangecroft, S., Wanders, N., and Van Lanen, H. A. J.: Drought in the Anthropocene, Nat. Geosci., 9, 89-91, https://doi.org/10.1038/ngeo2646, 2016.

Vicente-Serrano, S. M., Beguería, S., and López-Moreno, J. I.: A Multiscalar Drought Index Sensitive to Global Warming: The Standardized Precipitation Evapotranspiration Index, J. Climate, 23, 1696-1718, https://doi.org/10.1175/2009JCLI2909.1, 2010.

Waliser, D. and Guan, B.: Extreme winds and precipitation during landfall of atmospheric rivers, Nat. Geosci., 10, 179-183, https://doi.org/10.1038/ngeo2894, 2017.

Wang, S., Huang, J., He, Y., and Guan, Y.: Combined effects of the Pacific Decadal Oscillation and El Niño-Southern Oscillation on Global Land Dry-Wet Changes, Sci. Rep., 4, 6651, https://doi.org/10.1038/srep06651, 2014.

Ward, P. J., Beets, W., Bouwer, L. M., Aerts, J. C. J. H., and Renssen, H.: Sensitivity of river discharge to ENSO, Geophys. Res. Lett., 37, L12402, https://doi.org/10.1029/2010GL043215, 2010.

Ward, P. J., Jongman, B., Kummu, M., Dettinger, M. D., Sperna Weiland, F. C., and Winsemius, H. C.: Strong influence of El Niño Southern Oscillation on flood risk around the world, P. Natl. Acad. Sci. USA, 111, 15659-15664, 2014.

Ward, P. J., Couasnon, A., Eilander, D., Haigh, I. D., Hendry, A., Muis, S., Veldkamp, T. I. E., Winsemius, H. C., and Wahl, T.: Dependence between high sea-level and high river discharge increases flood hazard in global deltas and estuaries, Environ. Res. Lett., 13, 84012, https://doi.org/10.1088/17489326/aad400, 2018.
Wells, N., Goddard, S., and Hayes, M. J.: A Self-Calibrating Palmer Drought Severity Index, J. Climate, 17, 2335-2351, 2004.

Whittaker, J.: Graphical Models in Applied Multivariate Statistics, Wiley Publishing, Chichester, UK, 2009.

Xie, W., Xiong, W., Pan, J., Ali, T., Cui, Q., Guan, D., Meng, J., Mueller, N. D., Lin, E., and Davis, S. J.: Decreases in global beer supply due to extreme drought and heat, Nat. Plants, 4, 964-973, https://doi.org/10.1038/s41477-018-0263-1, 2018.

Yan, D. H., Wu, D., Huang, R., Wang, L. N., and Yang, G. Y.: Drought evolution characteristics and precipitation intensity changes during alternating dry-wet changes in the HuangHuai-Hai River basin, Hydrol. Earth Syst. Sci. 17, 2859-2871, https://doi.org/10.5194/hess-17-2859-2013, 2013.

Yang, T., Ding, J., Liu, D., Wang, X., and Wang, T.: Combined Use of Multiple Drought Indices for Global Assessment of Dry Gets Drier and Wet Gets Wetter Paradigm, J. Climate, 32, 737-748, https://doi.org/10.1175/JCLI-D-18-0261.1, 2018.

Yoon, J.-H., Wang, S.-Y. S., Lo, M.-H., and Wu, W.-Y.: Concurrent increases in wet and dry extremes projected in Texas and combined effects on groundwater, Environ. Res. Lett., 13, 54002, https://doi.org/10.1088/1748-9326/aab96b, 2018.

Zampieri, M., Ceglar, A., Dentener, F., and Toreti, A.: Wheat yield loss attributable to heat waves, drought and water excess at the global, national and subnational scales, Environ. Res. Lett., 12, 64008, https://doi.org/10.1088/1748-9326/aa723b, 2017.

Zhang, Q., Zhang, W., Chen, Y. D., and Jiang, T.: Flood, drought and typhoon disasters during the last half-century in the Guangdong province, China, Nat. Hazards, 57, 267-278, https://doi.org/10.1007/s11069-010-9611-9, 2011.

Zhang, Q., Gu, X., Singh, V. P., Kong, D., and Chen, X.: Spatiotemporal behavior of floods and droughts and their impacts on agriculture in China, Global Planet. Change, 131, 63-72, https://doi.org/10.1016/j.gloplacha.2015.05.007, 2015.

Zhong, S., Clark, M., Hou, X.-Y., Zang, Y.-L., and FitzGerald, G.: 2010-2011 Queensland floods: Using Haddon's Matrix to define and categorise public safety strategies, Emerg. Med. Aust., 25, 345-352, https://doi.org/10.1111/1742-6723.12097, 2013.

Zscheischler, J., Westra, S., van den Hurk, B. J. J. M., Seneviratne, S. I., Ward, P. J., Pitman, A., AghaKouchak, A., Bresch, D. N., Leonard, M., Wahl, T., and Zhang, X.: Future climate risk from compound events, Nat. Clim. Change, 8, 469-477, https://doi.org/10.1038/s41558-018-0156-3, 2018. 